\title{
Halk Sağlığı İçin Ciddi Bir Tehdit: Sosyal Medyada Tıbbi Bitki Reklamları Sosyal Medyada Tıbbi Bitkiler
}

\section{A Serious Threat to Public Health: Medicinal Plant Publicities in Social Media Medicinal Plants in Social Media}

\author{
İmran Altıkka ${ }^{1}$ (D) Afife Mat $^{2}$ (ib)
}

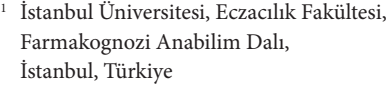

Sorumlu yazar/Corresponding author: Afife Mat,

İstanbul Üniversitesi, Eczacılık Fakültesi, Farmakognozi Anabilim Dall, İstanbul, Türkiye E-mail: afifemat@gmail.com

Geliş tarihi/Submitted: 14.06 .2020 İlk revizyon/First Revision Received: 13.01.2021 Son Revizyon/Last Revision Received: 15.01.2021 Kabul tarihi/Accepted: 21.01.2021

Atıf/Citation: Altıokka I, Mat A. A serious threat to public health: medicinal plant publicities in social media medicinal plants in social media. Sağlık Bilimlerinde İleri Araştırmalar Dergisi 2021; 4(1): 40-48.

https://doi.org/10.26650/JARHS2021-752686
ÖZ

Günümüzde yaygın olarak kullanılan tıbbi ve aromatik bitkiler hakkında internet ortamında yazılan bilgilerin doğruluğu bilimsel açıdan araştırılmıştır. En popüler 3 tıbbi bitki seçilerek sosyal medyada bu bitkilerin tanıtımı ve kullanım tavsiyeleri incelenmiștir. Sanal ortamda hiçbir filtreleme ya da denetleme mekanizması olmadan yayınlanan yanlış bilgilerin halk sağlığını tehdit edecek düzeyde olduğu kanısına varılmıştır. Bu reklamlara inanarak bitkileri kullananları bu tehlikeden korumak için sağlık yetkilileri tarafından bir kontrol mekanizması getirilmesi gerektiği düşünülmektedir.

Anahtar Kelimeler: Sosyal medya, Hypericum perforatum, Panax ginseng, Curcuma longa, drog-ilaç etkileșimi, tıbbi bitkilerin yanlış kullanımı

\section{ABSTRACT}

The accuracy of information on social media about widely used medicinal and aromatic plants was assessed scientifically. The three most popular medicinal plants were selected and how they were presented and the advice given about their use on social media were analyzed. As there is a lack of any regulations or filtering of information, misinformation on the internet was found to be a threat to the public health. It has been thought that a control mechanism has to be set by the health authorities in order to protect the people who are using these plants according to the unreliable information on the internet.

Keywords: Social media, Hypericum perforatum, Panax ginseng, Curcuma longa, drug-plant interactions, misuse of medicinal plants 


\section{GİRIŞ}

Yüzyıllardan beri geleneksel olarak kullanılan tıbbi ve aromatik bitkiler günümüzde de yaygın olarak kullanılmaktadır. Artan kanser vakaları, kimyasallarla beraber gelen birçok yan etki ve etkileşimler yüzünden bitkisel ilaçlar, "doğalsa zararsızdır” yaklaşımı ile çok ilgi görmektedir. Toplumun bu konuda artan merakı ve bilgi ihtiyacını karşılayan en büyük kaynak kuşkusuz sosyal medyadır. Tibbi ve aromatik bitkiler hakkında yazılan on binlerce yazı şu anda çevrimiçi ortamda okuyucularla buluşmaktadır. Bu yazıların yazarlarının veya bu web sitelerinin medikal anlamda bir geçmişinin, bilgi birikiminin olması zorunluluğu yoktur. Bitkisel ilaçlar hakkındaki yanlış inanışlar ve kontrolsüz bilgi paylaşımın sonuçları halk sağlığını ne yazık ki tehdit etmektedir.

Diğer taraftan bir bitkinin tıbbi amaçla kullanılabilmesi, yani drog olabilmesi için doğru türün doğru zamanda toplanmış olması gereklidir. Bitkinin kurutma ve saklama koşulları da kalitesine etki eder. Aktarlarda satılan droglar üzerinde yapılan kalite kontrol araştırmaları ne yazık ki durumun halk sağlı̆̆ını tehdit eder nitelikte olduğunu ortaya koymaktadır $(1,2)$.

Halk arasında tıbbi bitkiler hakkında "doğal olduğuna göre zararsızdır”, "doğaldır, bitkiseldir, hiçbir kimyasal bileşik içermez" şeklinde bir genel kanı hâkimdir. Yüzyıllardır nesilden nesile aktarılan tıbbi bitkilerin etkin bileşikleri ve farmakolojik etkileri günümüzde bilimsel araştırmalar ile aydınlatılmış bulunmaktadır. Kişinin sağlık durumu ve kullandığı ilaçlar dikkate alınmadan kullanılan bitkisel ilaçlar özellikle bitki-ilaç etkileşimleri nedeniyle büyük bir tehlike oluşturmaktadır. Tüm ilaçlar gibi bitkisel ilaçların da yan etkileri olabildiği gibi bitki-ilaç ve bitki-gida etkileşimleri de göz ardı edilmemelidir. Bitkisel ilaç verirken de kişinin genel sağlık durumu göz önüne alınmalı ve mutlaka hekimin bilgisi dâhilinde kullanılmalıdır. Halk arasında tüm bunların hiçbiri önemsenmemekte ve bitkisel ilaçlar tanıdıkların tavsiyesi ile ve medyadaki reklamlara inanarak kullanılmaktadır.

$\mathrm{Bu}$ çalışmada tıbbi ve aromatik bitkiler hakkında sosyal medyada yer alan yazılar bilimsel olarak mercek altına alınmış ve doğruluğu açısından değerlendirilerek sosyal medyadaki paylaşımların ne derece doğru olduğunu yorumlamak ve bu konuda yapılması gereken denetim mekanizmalarının gerekliliğini ortaya koymak amaçlanmıştır. Bunun için okuyucunun internete girdiği zaman yüksek olasılıkla karşılaşacağı sayfalar tespit edilerek en popüler on üç bitki seçilmiş ve yer alan bilgiler bilimsel kaynaklarla karşılaştırılmıştır.

Doğrularını ve yanlışlarını incelediğimiz bitkiler şunlardır: Hypericum perforatum, Panax ginseng, Curcuma longa.

Yanlış bilgilerin verildiği sosyal medya sitelerinin adresleri özellikle verilmemiştir.

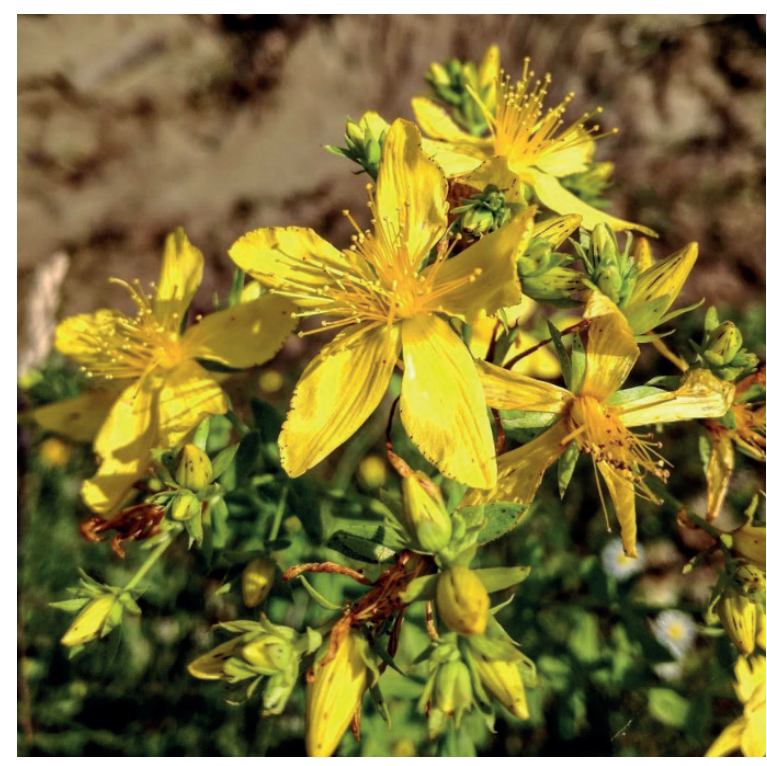

Resim 1. Hypericum perforatum -Saint John's Wort- Sar1 kantaron. (Fotoğraf:Dr.Ecz.Ezgi Ersoy)

Sarı kantaron yağı ve çayı şeklinde tıbbi amaçla harici uygulanarak ya da içilerek tüketilen oldukça popüler bir aromatik bitkidir (Resim 1). Drog olarak hyperici herba (çiçekli toprak üstü kısımları) kullanılır. Çiçekli dalların zeytinyağ iç̧inde 15 gün güneşte bekletilmesiyle kantaron yağı (Hyperici oleum) hazırlanır.

Sarı kantaron yüz yıllardır ülser, yara ve yanık tedavisi, diüretik, antibiyotik, antiviral etkileri ile kullanılmaktadır (3).Yapılan klinik çalışmalar sonucu hafif-orta dereceli depresyon tedavisinde de kullanılabileceği kanıtlanmıştır $(4,5)$.Yatıştırıcı, sikatrizan, antidepresan, antiseptik, antiviral etkileri vardır 
$(5,6)$. Yara ve yanık tedavisinde harici olarak uygulanır, çay olarak tüketildiğinde depresyon, korku ve endişe durumlarında geleneksel kullanımı vardır (7). Hypericum perforatum içeriğindeki naftadiantron türevi hiperisin, antidepresan etkiden sorumludur ve monoamin oksidaz inhibitorüdür $(8,9)$. Bunlara ek olarak yapılan son çalışmalar ile sarı kantaronun sitotoksik, analjezik ve antinosiseptif etkilerinin olduğu bulunmuştur (10).

Kontrendike olduğu durumlar organ transplantasyonlarından sonra, proteaz-1 inhibitörü kullanan HIV hastalarında, psikotik sendromlu ve intihar riski olan ağır depresyon hastalarıdır. Sarı kantaron cildi güneş ışığına karşı duyarlı hale getirdiğinden bu preparatları kullananların güneş ışığına çıkması sakıncalıdır (11).

Hypericum'un ilaçlar ile olan etkileşimleri yaygın olarak bilinir ve detaylı araştırılmıştır. Bazı ilaçların hızlı metabolize olmasına, kandaki miktarının azalmasına ve etkinliğin düşmesine sebep olur. Antidepresanların (özellikle SSRI) ise etkisinde artışa sebep olduğu düşünülmektedir. Çalışmalar Hypericum’un sitokrom p450 ve CYP3A4, p-glikoproteinin indükleyici ajan olduğunu göstermiştir (12). HIV proteaz inhibitörleri, varfarin, digoksin, oral kontraseptifler, teofilin, triptanlar ve SSRI'lar ile etkileşimde bulunur $(7,13)$.

\section{Sosyal medyada yer alan bilgiler}

- Egzema, varis gibi cilt rahatsızliklarında olumlu etkiler gösterdiği biliniyor. Yine dahilen iç ve dış varislerin tedavisinde etkilidir. Bunu damar büzücü özelliğiyle yapar.

- En önemli etkilerinden biriniyse kansere karşı gösteriyor ve kanserli hücrelerin büyüyüp çoğalmasını engelliyor.

- Vücudumuzdaki birçok hormonun düzenli bir şekilde salgilanmasina destek oluyor, bu sayede özellikle kadınlarm adet dönemlerinde sikça başvurdukları arasında yer alıyor.

- Adet sancilarinı dindirme konusunda etkili olduğu bilinen sarı kantaron, menopoz dönemindeki kadın larında sikça başvurduğu bitkilerden sayılıyor.
- Sarı kantaron aynı zamanda bel ve baş ağrısı gibi sıklikla yaşanan ağrılarında azalmasında önemli bir rol oynuyor.

- Mutluluk hormonlarinin salgilanmasin destekleyerek depresyon gibi olumsuz ve ciddi sorunlardan kurtulmaya yardimci oluyor.

- Ciltte oluşan sivilcelerle baş etmeyi de bilen sarı kantaron, sivilcelerden kalan izlerin de geçmesini sağllyor.

- Son olarak, güneş yanığı gibi dönemsel cilt lekelenmelerinde de olumlu etkileri olduğu için sıkça kullanılıyor.

- Pek çok Avrupa ülkesinde sarı kantaron otu yan etki vermeksizin kullanılmaktadir.

- Işstahı açıcıdır ve ciddi derecede ateş düşürür.

- Vücudu dinçlendirir ve kuvvet verir.

- Kas gevşetici özelliği vardır.

- Göğsü yumuşatır, öksürü̈̆̈̈ keser ve kişilerde rahatlama sağlar.

- Bronşit semptomlarında oldukça faydalidır.

- Korku, gerginlik, alt sslatma gibi sorunlarda faydalıdir.

- Bebeklerde görülen gaz sorunu ve karın ağrısina iyi gelir.

- Sinirsel olarak meydana gelen mide ağrilarını dindirir.

- Kekemelik sorununa iyi gelir ve sinirsel olarak düzelme sağlar.

- Grip sorununda etkisi görülmektedir.

- Balgam ve idrar söktürücü olarak kullanılır.

- Nekahet dönemini kısaltrr.

- Bağirsaklarda oluşan solucanlarm dökülmesini sağlar.

- Sarılık hastalığı olan kişilerde çayının faydası kanitlanmıştır. Ancak ilerlemiş sarılık durumlarında hap şeklinde de kullanılabilinir.

- Gut hastalığına da iyi gelir.

- Kan basıncını düşürür. Tüm bunların sonucunda oluşabilecek kalp hastalıklarını da engeller.

- Son zamanlarda sarı nokta hastalığı tedavisinde de kullanılır. Bu şekilde hastalığı büyük ölçüde engellemiş ve görme rahatsıliğı olan kişilerin körlük durumlarını büyük ölçüde azaltmıştır. 
- Safra kesesi ve karaciğer gibi organların iyi çalışması içinde kantaron çayı tüketilmesi tavsiye edilir.

- Sedefhastalı̆g gibi cilt hastalıklarma iyi gelir.

- Kan şekerinin düşürülmesine yardımcı olur.

- Pürüzsüz bir cilde sahip olabilmek için, cilt bakım yağı olarak yararlanabilirsiniz.

- Bebeklerde pişiklere iyi gelmektedir.

- Trafik kazaları sonucu meydana gelen içyaralanma ve iç kanamalarda hem sürüler ek, hemde dahilen içilerek kullanılır. Damar büzücü oluşu sebebiyle iç kanamalarm durmasina yardimci olur.

- Hematomlarda (derideki mavi-mor lekeler), beze șişkinliklerinde ilgili bölgeye sürülüp masaj yapilır.

- Hemoroide sebep olan kabızliğı önleyerek hemoroidin en çok acı veren kısmında kişiye rahatlama sağlar.

- Cildin yaşlanmasın önlüyor. Vücutta hücre yenilenmesini sağlar.

- Zona hastalı̆̆ına iyi geliyor.

- Ses kısıkliğın tedavi ediyor.

- Böbrek ve mesanedeki taşları eritmeye, bağırsak solucanlarını düşürmeye yardımcı oluyor. Ayrica ishali tedavi ediyor.

\section{Sosyal medyadaki yanıltıcı bilgiler}

Öncelikle Hypericum perforatum bitkisinin birçok ilaçla etkileşimi bulunmaktadır ve bu nedenle kullanım amacı ne olursa olsun hekim veya eczacı denetiminde tüketilmesi gerekir. İnternette bahsedilen cilt lekeleri, akne ve sedef rahatsızlıkları üzerine olan etkilerinin doğruluğundan önce sarı kantaronun ciltte 1şığa hassasiyete neden olduğunu bu nedenle gündüz kullanımında lekelenmelere neden olabileceği unutulmamalıdır.

Bebeklerde kullanımından ve ateş düşürücü etkisinden bahsedilmiştir ancak bilindiği gibi bebekler, hamvileler ve yaşlılar özel hasta gruplarıdır. Bu hasta gruplarında dozlama oldukça önemlidir. Ancak söz konusu bitki olunca toplumun genel algısı nedeniyle zararsız olduğu düşünülüp yüksek dozlarda uygulanabilir. Sarı kantaronun depresyon üzerine etkileri literatürde bilinmektedir ve sosyal medyada da sıkça yer almıştır. Ancak hali hazırda antidepresan kullanan hastalarda etkisi kontrendikedir. Hastanın sarı kantaronla birlikte antidepresan kullanması oldukça tehlikeli sonuçlara neden olabilir. Ayrıca birisi kabızlığı önlediğini iddia ederken, bir diğeri ishale karşı önermektedir.

$\mathrm{Bu}$ reklamlarda yer alan diğer etkiler üzerine literatürde yer alan herhangi bir çalışma yoktur.

Çin tıbbında geleneksel kullanımı olan Panax

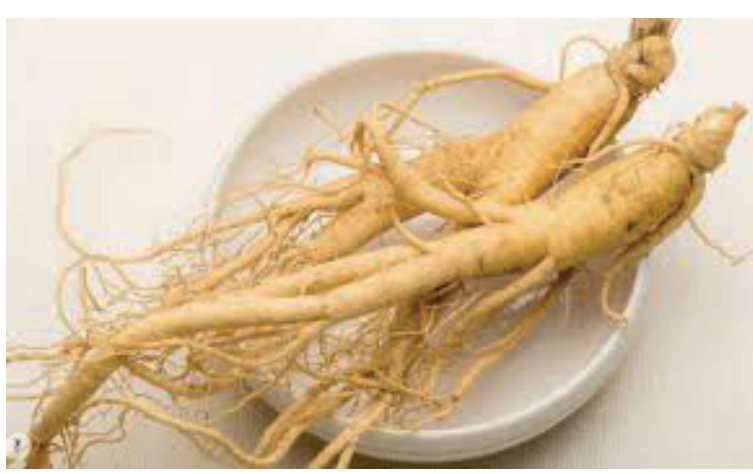

Resim 2. Panax ginseng C.A.Mey - Ginseng - Man root. (Fotoğraf: Kemal Onur Özman, Doğa dergisi 2017)

ginseng, günümüzde batıda da yaygın bir kullanılışa sahip olmuştur. Panax ginseng'in drog olarak kullanılan kısmı kökleri olan ginseng radix'tir. Panax ginseng, Kore veya Asya ginseng'i olarak da bilinmektedir. Panax ginseng'in aktif içerikleri triterpen saponinler olan ginsenositlerdir (Resim 2).

Çinli düşünürlere göre, ginseng insanı hayat enerjisi ile doldurur, sağlıklı ve uzun bir yaşamı destekler. Batılı herbalistler tarafından midevi olarak, anoreksi tedavisinde ve mental tükenmekten doğan sindirim sistemi rahatsızlıklarında kullanılmıştır (5) .

Bilinen etkileri, immun sistemini güçlendirici, hücre gelişimini destekleyici, insülin hassasiyetini olumlu yönde geliştiren, düzenli kullanımda kanser önleyici olabilen, immunomodulatör, kardiyotonik, RNA ve protein biyosentezine yardımcı olmasıdır (5). Bunlarla beraber antienflamatuar, antioksidan ve antikanser olarak literatürde yer almaktadır (14). Baytop, ginseng'in etkilerini yorgunluk giderici ve kalp kuvvetlendirici olarak belirtmiştir (4) . 
Ancak sürekli kullanım sağlıklı değildir ve yaşılarda önerilmemektedir (5). Mensturasyon, akut astım, burun kanaması ile kontrendikedir (5). Hipertansiyon ve hipotansiyonu olan, kan basincinda anormallikler yaşayan hastalarda advers etkilere neden olabilir (14). Kafein ve amfetamin gibi stimülanlarla kullanımından kaçınılmalıdır. Akut enfeksiyon durumlarında da bu durum geçerlidir. Ginseng varfarinin antikoagülan aktivetisinde düşüşe sebep olur, ancak bu etkileşimin nasıl olduğu net değildir (5). Diyabet hastaları doktora danışmadan ginsengi kullanmamalıdır (12). Sildenafil, hipoglisemik ilaçlar, CNS stimülanları da olası etkileşim gruplarıdır (15). Gebelik ve laktasyon kategori A'dır. Emziren annelerde geleneksel olarak da kullanımı vardır. Laktasyon döneminde kullanılabilir (5).

\section{Sosyal medyada yer alan bilgiler}

- Kötü kolesterol üzerinde de dengeleyici etkileri bulunan ginseng, düzenli ve ölçülü kullanıldiğında kolesterolü düşürüyor. Aynı şekilde tansiyonunda sağllklı bir düzeyde seyretmesine destek oluyor.

- Afrodizyak etkisi olduğu da bilinen ginseng, hormonlarm düzenli olarak üretilmesine yardimcı oluyor.

- Güçlü antioksidan özelliği sayesinde vücudu sadece grip, nezle gibi basit hastalıklara karşı güçlendirmeyen ginseng, aynı zamanda kanser gibi ciddi rahatsızlıklarda da kendini gösteriyor, kansere yakalanma riskini azaltıyor. Oluşmuş olan kanserli hücrelerinse büyümesini ve çoğalmasını olabildiğince yavaşlattığ 1 söyleniyor.

- Diyabet tedavisinde, erkeklerde cinsel fonksiyon bozukluklarında, kan şekerini düşürmede ve kan kolestrolünü azaltmada kullanılır.

- Gözlere parlaklık vermek, güç kazanmak ve pek çok hastalık için kullanmışlar ve bu durum bir ticarete dönüşmüştür.

- Ginseng kökleri stres, anksiyete, bulantı, kusma, baş ăgrısı, hazımsızlik, ishal, akciğer sorunları, artrit astım, Crohn hastalı̆̆, tümörler, yorgunluk, şeker hastaliğl, depresyon, diş ve diş eti hastalıkları gibi hastalıklara faydalıdır.
- Mide sorunlarina faydalıdir. Bir yumuşatıcı ve bir uyarıcı olarak çalışır ve sindirim sisteminin sorunsuz ve verimli çalışmasını sağlar.

- Kökler yorgunluk, sinirlilik ve travma gibiçeşitli stres faktörlerine karşı vücudun direncini artırır. Menstruasyonu düzenlemek, doğum ăgrılarını azaltmak için kullanılabilir.

- Ginseng hafizayı arttırarak öğrenme yeteneklerini geliştirebilir. Alzheimer hastalı̆̆ında kullanilır.

- Ginseng kökleri karaciğer ve kalbin sorunsuz çalışmasını sağlayarak kan şekeri ve kolestrol seviyelerini düzenler.

- Solunum sisteminin verimli çalışmasına yardimcı olur.

- Ginseng anemiye iyi gelir.

- Ginsengin kadinlar üzerindeki beynin hafiza (bellek) merkezlerini uyarıcı etkisinin bulunmast ise yenidir.

- Karaciğeri toksinlerden temizler. Ayrıca radyoterapinin yan etkilerini azaltır Bronşitin, astım ve dolaşım problemlerinin tedavisinde yararlıdir

- Ginseng çayının fazla tüketilmesinin herhangi bir sakıncası olmadığı gibi büyük faydaları vardir.

- Bronşit ya da astım gibi rahatsızliklar nedeniyle sorun yaşayan kişilerin faydalanabileceği bir takviyedir. Bu hastaliklara iyi gelmesi ile bilinmektedir.

- Diş ve diş eti hastahkları gibi rahatsızlıklar yaşayan kişilere yardımcı olabilecek özellikleri vardir.

\section{Sosyal medyadaki yanıltıcı bilgiler}

Ginseng'in yaşlılarda kullanımı önerilmez ve sürekli kullanıma uygun bir bitki değildir. Buna rağmen internette fazla oranda tüketilmesinde herhangi bir sakınca olmadığı ifadesine yer verilmiştir. Ayrıca tansiyonun düzenli seyri için önerilmiş olan ginseng, aksine hipertansiyon ya da hipotansiyonu olan hastalarda kontrendikedir.

Panax ginseng'in insulin hassasiyetini geliştirdiği ve tip 2 diyabette etkili olduğu bir çok çalışmada 
gösterilmiş olsa da bu bilgileri "kesin çözüm", "ilaçsız tedavi" şeklinde ifade etmek oldukça risklidir. Panax ginsengin’in oral hipoglisemik ilaçlarla kullanımı kan şekerinde ani düşüşlere neden olabilir. Ayrıca hastaların aktarlardan aldıkları bu bitkiler standardize olmadıklarından, dozlamanın yapılamaması gibi faktörler de ginseng gibi tıbbi bitkilerin kronik hastalıkların tedavisinde kullanımlarında temel sıkıntıdır. Şeker ya da tansiyon hastalarına tıbbi bitkilerin etken maddelerinin miktarları bilinmeden, herhangi bir dozlama yapmadan verilen bu tavsiyeler aksi yönde etkilere neden olacaktır.

Alzheimer tedavisinde ginseng kullanımı literatürde de yer alan ve umut verici sonuçlara ulaşılmış bir konudur. Ancak AD tedavisinde kullanıldığı bilgisi doğru değildir. Bu çalışmalarda panax ginseng'in etken maddesi ginsenosid (ginseng saponini) ve gintonin ya da ginseng proteinleri standardize şekilde sabit dozlarda uygulanmıştır $(16,17)$. Dolayısıyla çay ya da piyasada bulunan besin destek takviyeleri ile alınan panax ginseng' in de aynı etkileri sağlayacağ ${ }^{-}$ nı söylemek bilimsel bir yaklaşım olmamaktadır.

Bone ve Mills ginsengin astım ile kontrendike olduğunu belirtmiştir ancak internette sıkça astıma iyi geldiğinden bahsedilmiştir. Panax ginseng'in astım üzerine terapötik etkisi ile ilgili yapılan klinik çalışmalar sınırlıdır. Metaanaliz çalışmaları ile bu etkiden bahsetmek için yeterli bir verinin olmadığı açıklanmaktadır (18).

Cucuma longa L. Zingiberaceae familyasına ait Curcuma cinsinin 133 türünden biridir (19). Curcu-

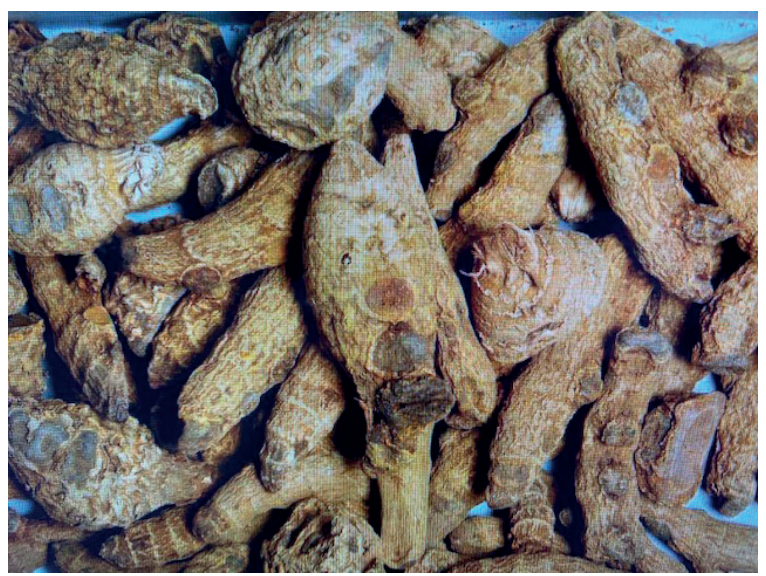

Resim 3. Curcuma longa L.- Turmeric-Zerdeçal (Fotoğraf: Ebru Kuruldak, Bitirme projesi, 2019) ma longa bitkisinin rizomu (yeraltı sapı) olan Curcumae longae rhizoma drog olarak kullanılmaktadır. Curcumae longae rhizoma'da bulunan major aktif bileşenler kurkumunoidler ve uçucu yağlarıdır (2). Hindistan'da ve Güney Doğu Asyadda çoğu şehirde tarımı yapılmaktadır. Zerdeçala sarı rengini veren pigment kurkumin isimli aktif bileşenidir (Resim 3).

Zerdeçal'ın geleneksel kullanımı oldukça yaygındır. Güney Asya'da kesikler ve yanıklarda antiseptik, antibakteriyel olarak, Pakistan'da irritabl bağırsak sendromunda, gastrointestinal sorunları gidermek için, Afganistan'da yaraları temizlemekte, Hindistan'da cildi güzelleştirmek, kanı temizlemek için kullanılmaktadır (19).Geleneksel Çin tıbbında karın ağrısı ilişkili tedavilerde karminatif amaçlı kullanılmaktadır (20). Curcuma longa'nın farmakolojik etkilerini antifungal, antienflamatuar, antimikrobiyal, antioksidan, antidiyabetik, hepatoprotektif, antikanser, kolestrol düşürücü ve karminatif olarak sıralamak mümkündür (2). Bunlarla birlikte Alzheimer, Parkinson, multiple skleroz ve astım hastalıklarında zerdeçal kullanımı ile pozitif yanıtların alındığı çalışmalar literatürde mevcuttur. Ancak bu araştırmalar daha çok in-vivo ve in-vitro düzeyde olup klinik çalışmalar henüz az sayıdadır $(21,22,23,24)$.

Önerilen dozlarda uzun süre kullanımı güvenlidir. Safra yolu tıkanıklığında kontrendikedir, uzmanların önerisi dışında kullanılmamalıdır (5). Antiplatelet ve antikoagülan tedavisiyle beraber kullanılmamalıdır (25). Topikal amaçla kullanılan zerdeçalda hastalar çok fazla miktarda güneş ışı̆̆ına maruz kalmamalıdır, in vitro çalışmalarda fototoksik etkileri olduğu görülmüştür. Zerdeçal CYP450 enzimi ile metabolize olur ve bu yolak ile metabolize olan ilaçların farmakokinetiğini değiştirmektedir (26).

\section{Sosyal medyada yer alan bilgiler}

- Içeriğinde yer alan kurkumin kansere yakalanan kişilerde kanser hücrelerinin yayılmasını geciktirmektedir.

- İlerleyen yaş ile birlikte gelen bunama ve Alzheimer hastalı̆̆na yakalanma riskini büyük oranda artmaktadır. Beyinde oksijen artışını hızlandırarak hastalı̆̆ın ilerlemesini yavaşla- 
tabilir hatta durdurabilir.

- Tip 2 Diyabet'i iyileştirir.

- İçerdiğgi zengin asitler mide sağhl̆ğ için faydalıdır. Midenin ihtiyaç duyduğu asit ve asit oranin dengeler.

- Zerdeçal çayı kan pihtılaşmasını önler.

- Çok iyi bir antidepresandir, sinirleri ve kaslarl güçlendirir, sakinleştirir.

- Sedef hastalğ̆ı gibi cilt hastalıklarma iyi gelir.

- Saç dökülmesi, saçkıran gibi rahatsızliklara da fayda sağlar.

- Yapılan araştırmalara göre çocuklukta lösemiye yakalanma oranını düşürür.

- Verem gibi hastaliklarda faydalidir.

- Safra kesesi ve safra yollarinin fonksiyonel hastalıklarına karşı etkisi zerdeçal yararları arasindadir.

\section{Sosyal medyadaki yanıltıcı bilgiler}

İnternette zerdeçalın dermatolojik rahatsızlıklar üzerine etkileri (saçkıran, saç dökülmesi, sedef, ağız yaraları) yer almaktadır. Literatürde saçkıran ve saç dökülmesi hakkında curcumin ile yapılan bir çalışma bulunmamaktadır. Psoriazis'te curcumin ile pozitif sonuçlara ulaşılan çalışmalarda belirli dozlarda zerdeçalın etken maddesi curcuminoid ya da curcumin oral yoldan verilmiştir. Yapılan klinik çalışmaların da hepsi olumlu sonuçlanmamıștır (27). Dolayısıyla 'sedef hastalığından zerdaçalla kurtulabilirsiniz' şeklinde verilen tavsiyeler bilimsel ve etik değildir.

Felç (inme) tedavisi oldukça zor olan nörodejeneratif bir hastalıktır. Zerdeçaldan sentezlenen bazı aktif içeriklerin nörolojik koruyucu etkileri hakkında çalışmalar vardır ancak genellikle felci önleyici olarak araştırılmıştır. Bilindiği gibi nörolojik rahatsızlıklarda tedaviyi zorlaştıran kan beyin bariyeri gibi fiziksel ve kimyasal kısıtlayıcı faktörler bulunmaktadır. Zerdeçal çayını felci tedavi edebilmeyi umut ederek tüketen hastalar bir fayda sağlayamayacakları gibi aynı anda varfarin gibi bir kan sulandırıcı ya da kolestrol ilacı kullanıyorsa ilaç-bitki etkileşimlerinden ötürü zarar da görebilecektir. Özellikle yaşlı hasta gruplarında tıbbi bitki tüketimi uzman gözetiminde olmalıdır.
Zerdeçalın safra arttırıcı özelliği bulunmaktadır ve safra yolu tıkanıklığında kontrendike olduğu belirtilmiştir. İnternette ise safra yollarının fonksiyonel rahatsızlıklarında zerdeçal kullanılmasının faydası olduğundan bahsedilmektedir.

Zerdeçalın antikanser etkileri bulunduğu birçok yayın ile destekleniyor olsa da kanser hastaları özel hasta gruplarıdır ve kullandıkları tüm besin destek takviyeleri doktor gözetiminde olmalıdır. Onkologlar antioksidan kullanımını kemoterapi ve radyoterapi esnasında önermemektedir dolayısıyla zerdeçal kemoterapiklerin farmakokinetiğini etkileyebilir $(28,29)$.

Zerdeçalın çeşitli etkileri üzerinde yapılan araştırmaların olumlu sonuç verildiği görülse de, ilaç olarak önerilmesi için klinik çalışmaların henüz yeterli sayıda olmadığı unutulmamalıdır.

'Zerdeçal kan pıhtılaşmasını önler' bilgisi doğru olsa da bu özelliği zerdeçalın antikoagülanlarla beraber kullanılmaması gerektiği anlamına da gelmektedir. Aynı şekilde zerdeçal antidepresanlarla etkileşime girerek bazı antidepresanların farmakokinetiğinde değişikliklere neden olabilmektedir (26). Zerdeçalın antioksidan ve antienflamatuar özellikleri nedeniyle nekahat devresinde kullanabileceği belirtmiştir ancak ilaç-bitki etkileşimleri sebebiyle doktor gözetiminde bu tüketimin olması daha sağlıklı olacaktır.

Bunlara ek olarak zerdeçal'a ait katarakt ve mide asidini dengeleme üzerine etkileri hakkında literatürde bir çalışmaya rastlanılamamıştır.

\section{SONUÇ VE TARTIŞMA}

Sosyal medyada bitkilerin tedavi edici özellikleri hakkında yazılanlar ve yapılan öneriler incelendiğinde büyük bir kısmının hatalı olduğu görülmüştür. Bunun gibi birçok yanlış uygulamalar toplum sağlığı tehdit etmektedir. Bu tehlikelere örnek olarak uzun vadede organ yetmezliği, çeşitli dermatolojik sıkıntılar, kronik rahatsızlıklarda oluşacak kontrendike durumlar ve çeşitli ilaç-drog etkileşimleri örnek verilebilir.

Tibbi bitkiler hakkında internette verilen bilgilerin kaynakları belirtilmediği gibi, 'mucize' etkilere 'kesin' olarak sahip olduklarından bahsedilmektedir. Bununla birlikte "hicbir yan etkisi yoktur", "ilaclardan daha etkilidir", "kesin tedavi yontemidir", 
"hergun icilebilir" gibi toplum sağlığını tehdit eden keskin ifadeler kullanılmıştır. Özellikle diyabet, kolesterol, kalp rahatsızlıkları gibi kronik hastalığı bulunan kişilerin hali hazırda düzenli ilaç kullanan hastalar olduğu düşünüldüğünde, ilaç-drog etkileşimleri ile risk taşıyan durumlar ortaya çıkabilir. Kanser hastalarının doktorlarının bilgisi olmadan herhangi bir besin destek takviyesi veya ilaç kullanması asla önerilmemektedir. Ancak internette yazan "tümörün büyümesini durdurur", "kanseri yok eder" şeklinde hastayı tıbbi bitki tüketimine teşvik eden yazılar hastalığa olumlu yönde katkı sağlamaktan ziyade ilerlemesine neden olabilir. Deri hastalıklarında ise bazı tıbbi yağların sikatrizan etkileri yanında fotosensibiliteye de neden olabildikleri unutulmamalıdır. Bu sebeple bu tür uygulamalar hastaya fayda sağlamak yerine tedaviyi güçleştiren yeni sorunlar oluşmasına neden olabilmektedir.

İnternette yer alan bu bilgilerin bazı çalışmalardan alındığını görmekteyiz. Ancak her akademik çalışmanın sonuçlarını genellemek, kesin bir sonuç şeklinde yansıtmak ve aksini iddia eden yayınları yok saymak özellikle konu sağlık olunca tehlikeli bir yaklaşımdır. Bahsi geçen çalışmalarda kullanılan tıbbi bitkilerin standardize olduğu, bazen yalnızca etken maddelerinin esktre edilip verildiğini ya da vücuda veriliş yollarının farklılık gösterdiğini uzmanların bu yayınları değerlendirirken birçok parametreyi hesaba kattığını unutmamak gerekir.

Sanal ortamda paylaştığımız bilgilere erişim oldukça kolay olduğu için bu kanalı daha doğru ve etkin kullanmak toplumsal sağlık için gereklidir. Bitkisel tedaviler de ilaç ile tedavi yaklaşımı gibi bilimsel olmalı ve uzmanların önerileri ile uygulanmalıdır. Aksi takdirde kontrolsüz hale gelen fitoterapi uygulamaları tedavisi daha zor hastalıklar olarak geri dönecektir. Bu sebeple sanal ortamda konunun uzmanları tarafından tıbbi ve aromatik tedavi yöntemleri hakkındaki paylaşımlar denetlenmelidir.

Hakem Değerlendirmesi: Dış bağımsız.

Peer Review: Externally peer-reviewed.

Yazar Katkıları: Çalışma Konsepti/Tasarım- A.M., İ.A.; Veri Toplama- İ.A.; Veri Analizi/Yorumlama-
A.M., İ.A.; Yazı Taslağ1- İ.A.; İçeriğin Eleştirel İncelemesi- A.M.; Son Onay ve Sorumluluk- A.M., İ.A.

Author Contributions: Conception/Design of Study- A.M., İ.A.; Data Acquisition- İ.A.; Data Analysis/Interpretation- A.M., İ.A.; Drafting Manuscriptİ.A.; Critical Revision of Manuscript-A.M.; Final Approval and Accountability- A.M., İ.A.

Çıkar Çatışması: Yazarlar çıkar çatışması beyan etmemişlerdir

Conflict of Interest: Authors declared no conflict of interest.

Finansal Destek: Yazarlar finansal destek beyan etmemişlerdir.

Financial Disclosure: Authors declared no financial support.

\section{KAYNAKLAR}

1. Tavlı ÖF, Hazman Ö, Büyükben A, Yılmaz FN, Özbek Çelik B, Eroğlu Özkan E. İstanbul Aktarlarında satılan Hypericum perforatum örneklerinin farmakognozik açıdan incelenmesi, Ankara Ecz Fak Der 2020;44(2):265-80.

2. Kuruldak E. Curcumae longae rhizoma drogunun tedavi değeri ve kalite kontrolü, Bitirme Projesi, İstanbul Üniversitesi Eczacilık Fakültesi, Farmakognozi Anabilim Dal,, Danışman: Afife Mat. 2019, 38.

3. Bombardelli E, Morazzoni P. Hypericum perforatum. Fitoterapia (Milano), 1995;66(1):4368.

4. Baytop T. Türkiyede bitkiler ile tedavi (geçmişte ve bugün) Nobel Tip Kitabevi, İstanbul; 1984:166-7.

5. Bone K, Mills S. Principles of herbal pharmacology. Principles and Practice of Phytotherapy: Modern Herbal Medicine; Churchill Livingstone: New York, NY,USA,2013;1056.

6. Barnes J, Anderson LA, Phillipson JD. St John's wort (Hypericum perforatum L.): a review of its chemistry, pharmacology and clinical properties. J Pharm Pharmacol 2001;53(5):583-600.

7. Henderson L, Yue QY, Bergquist C, Gerden B, Arlett, P. St John's wort (Hypericum perforatum): 
drug interactions and clinical outcomes. Br J Clin Pharmacol 2002;54(4);349-56.

8. Suzuki O,Katsumata Y,Oya M, Bladt S,Wagner H. Inhibition of monoamine oxidase by hypericin. Planta Med 1984;50(3):272-4.

9. Mennini T, Gobbi M. The antidepressant mechanism of Hypericum perforatum. Life sciences 2004;75(9):1021-7.

10. Ersoy E, Eroğlu Özkan E, Mat A. Yeni çalışmalar 1şı̆̆ında Hypericum türlerinin farmakolojik aktiviteleri, Sağlık Bilimlerinde İleri Araştırmalar Dergisi 2019;2(2):71-9.

11. Ernst E, Rand JI, Barnes J, Stevinson C. Adverse effects profile of the herbal antidepressant St. John's wort (Hypericum perforatum L.). Eur J Clin Pharmacol 1998;54(8):589-94.

12. Escop, European Scientific Cooperative on Phytotherapy. The scientific foundation for herbal medicinal products. ESCOP Monographs:2 nd edition Edition second 2003;211: 257.

13. Johne A, Brockmöller J, Bauer S, Maurer A, Langheinrich $M$, Roots I. Pharmacokinetic interaction of digoxin with an herbal extract from St John's wort (Hypericum perforatum). Clin Pharmacol Ther 1999;66(4):338-45.

14. Kiefer DS, Pantuso T. Panax ginseng. Am Fam Physician 2003;68(8):1539-42.

15. Schulz V, Hänsel R, Blumenthal M, Tyler VE. Rational phytotherapy: A reference guide for physicians and pharmacists., Springer Science \& Business Media. Verlag Berlin Heildelberg,Printed in Germany 2004; 373.

16. Li H, Kang T, Qi B, Kong L, Jiao Y, Cao Y. et al. Neuroprotective effects of ginseng protein on PI3K/Akt signaling pathway in the hippocampus of D-galactose/ $\mathrm{AlCl} 3$ inducing rats model of Alzheimer's disease. J Ethnopharmacol 2016;179:162-9. 17. Kim HJ, Jung SW, Kim SY, Cho IH, Kim HC. et al. Panax ginseng as an adjuvant treatment for Alzheimer's disease. J Ginseng Res 2018;42(4):401-11.

18. Liu F, Xuan NX, Ying SM, Li W, Chen ZH, Shen HH. Herbal medicines for asthmatic inflammation: from basic researches to clinical applications. Mediato Inflamm 2016:6943135.

19. Prasad S, Gupta SC, Tyagi AK, Aggarwal BB. Curcumin, a component of golden spice: from bedside to bench and back. Biotechnol Adv 2014; 32(6):1053-64.

20. Aggarwal BB, Takada Y, Oommen OV. From chemoprevention to chemotherapy: common targets and common goals. Expert Opin Invest Drugs 2004;13(10):1327-38.

21. Mishra S, Palanivelu K. The effect of curcumin (turmeric) on Alzheimer's disease: An overview. Ann Indian Acad Neurol 2008;11(1):13.

22. B Mythri R, M Srinivas Bharath M. Curcumin: a potential neuroprotective agent in Parkinson's disease. Current Pharm Des 2012;18(1):91-9.

23. Xie L, Li XK, Takahara S. Curcumin has bright prospects for the treatment of multiple sclerosis. Int Immunopharmacol 2011;11(3):323-30.

24. Kurup VP, Barrios CS. Immunomodulatory effects of curcumin in allergy. Mol Nutr Food Res 2008;52(9):1031-9.

25. Daveluy A, Géniaux H, Thibaud L, Mallaret M, Miremont-Salamé G, Haramburu F. Probable interaction between an oral vitamin K antagonist and turmeric (Curcuma longa).Therapie 2014;69(6):519-20.

26. Bahramsoltani R, Rahimi R, Farzaei MH. Pharmacokinetic interactions of curcuminoids with conventional drugs: A review. J Ethnopharmacol 2017; 209:1-12.

27. Kurd SK, Smith N, VanVoorhees A, Troxel AB, Badmaev V, Seykora JT, Gelfand JM. Oral curcumin in the treatment of moderate to severe psoriasis vulgaris: A prospective clinical trial. J Am Acad Dermatol 2008;58(4):625-31.

28. D'Andrea GM. Use of antioxidants during chemotherapy and radiotherapy should be avoided. CA Cancer J Clin 2005;55(5):319-21.

29. Somasundaram S, Edmund NA, Moore DT, Small GW, Shi YY, Orlowski R. Z. Dietary curcumin inhibits chemotherapy-induced apoptosis in models of human breast cancer. Cancer research 2002;62(13):3868-75. 